\title{
ÆUSGS
}

science for a changing world

\section{Observations and Recommendations Regarding Landslide Hazards Related to the January 13, 2001 M-7.6 E1 Salvador Earthquake}

By Randall W. Jibson and Anthony J. Crone

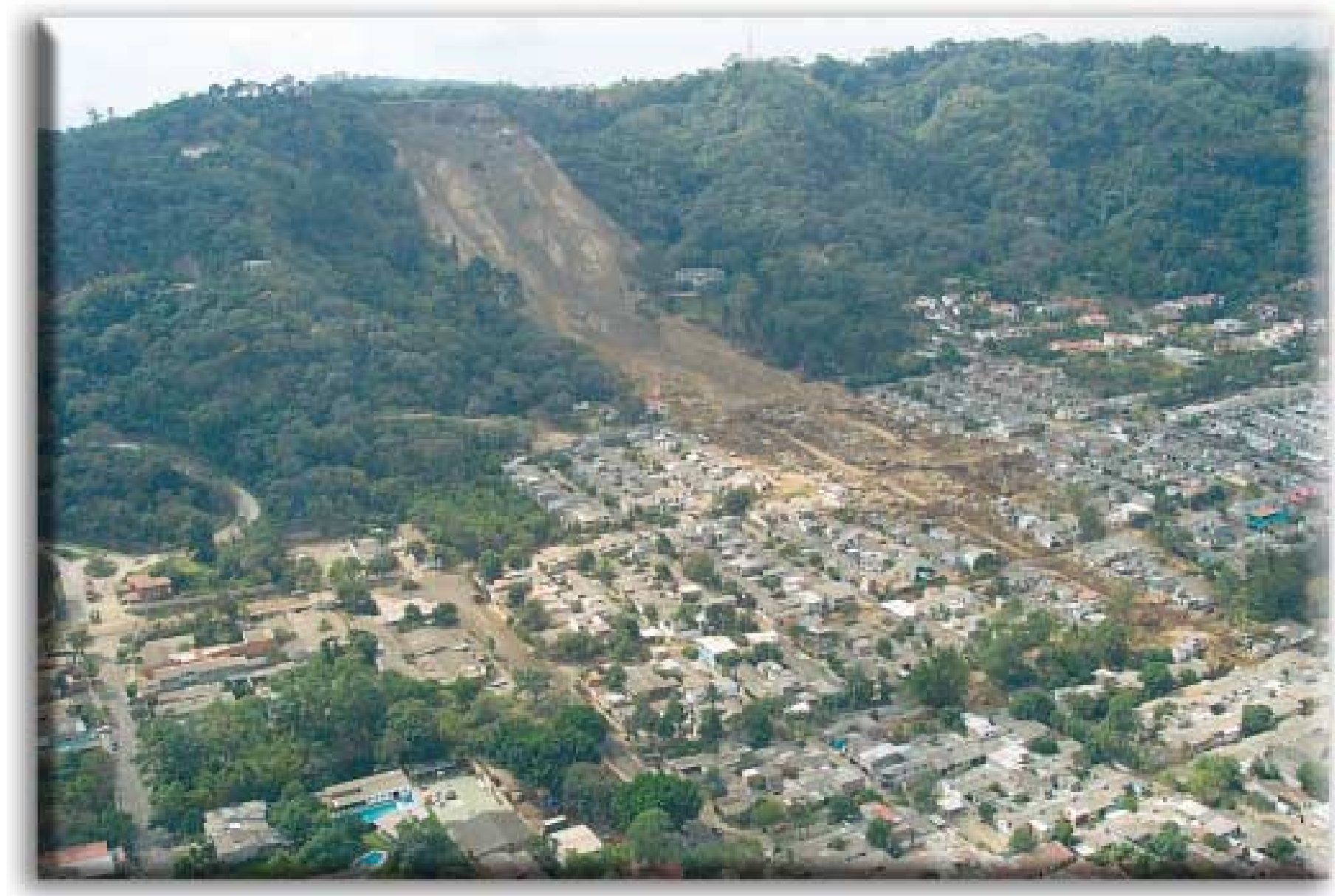

Open-File Report 01-141

On-line Edition

2001

U.S. Department of the Interior

U.S. Geological Survey 


\section{Observations and Recommendations Regarding Landslide Hazards Related to the January 13, 2001 M-7.6 E1 Salvador Earthquake}

By Randall W. Jibson and Anthony J. Crone

\section{Open-File Report 01-141 On-Line Edition}

\section{U.S. Geological Survey}

Box 25046, MS 966

Denver Federal Center

Denver, Colorado 80225-0046

jibson@usgs.gov

This report is preliminary and has not been reviewed for conformity with U.S. Geological Survey editorial standards nor with the North American Stratigraphic Code. Any use of trade names in this publication is for descriptive purposes only and does not imply endorsement by the U.S. Government.

2001

U.S. Department of the Interior

U.S. Geological Survey 
$\mathrm{T}$ he January 13, 2001 earthquake (M-7.6) off the coast of El Salvador triggered widespread damaging landslides in many parts of the El Salvador. In the aftermath of the earthquake, the Salvadoran government requested technical assistance through the U.S. Agency for International Development (USAID); USAID, in turn, requested help from technical experts in landslide hazards from the U.S. Geological Survey. In response to that request, we arrived in El Salvador on January 31, 2001 and worked with USAID personnel and
Salvadoran agency counterparts in visiting landslide sites and evaluating present and potential hazards. A preliminary, unofficial report was prepared at the end of our trip (February 9) to provide immediate information and assistance to interested agencies and parties. The current report is an updated and somewhat expanded version of that unofficial report. Because of the brief nature of this report, conclusions and recommendations contained herein should be considered tentative and may be revised in the future.

\section{SUMMARY OF LANDSLIDE TYPES AND DISTRIBUTION}

A

n unofficial report by Edwin L. Harp and James Vallance of the U.S. Geological Survey (Landslide Hazards in El Salvador Triggered by the January 13, 2001 Earthquake) briefly summarized the regional extent and types of landslides triggered by the earthquake. Most of the triggered landslides were relatively shallow falls and slides in rock and debris primarily within young volcanic pyroclastic deposits. Two notable exceptions to this generalization are the landslide from Balsamo Ridge that destroyed much of the Las Colinas neighborhood of Santa Tecla and the landslide near San Vicente that blocked the Pan American Highway. Both of these landslides were deep, massive slides of large volume and devastating consequences. Geologic units most affected by landslides include the Balsamo Formation and the younger pyroclastic units that overlie the Balsamo Formation; among these overlying materials, the Tierra Blanca 4 unit is particularly prone to failure. Areas most affected by landslides include the Cordillera Balsamo region west and south of San Salvador, areas around Lago de Ilopongo and Lago Coatepeque, slopes on the flanks of volcanoes in the southern part of the country (particularly Usulutan Volcano), and several slopes around San Salvador proper. 
$\mathrm{L}$ andslides are a normal occurrence in the geologic setting of $\mathrm{El}$ Salvador. The active tectonic environment near a plate boundary that produces steep topography; the relatively young, weak volcanic rocks; the warm, humid sub-tropical climate with the heavy rains of the wet season; and the frequency of moderate and large earthquakes all contribute to an environment prone to landsliding.

In the areas that experienced landslides in the January earthquake, two broad types of volcanic rocks are present: relatively soft, weak pyroclastic deposits and stronger indurated rocks that originated as lava flows. The pyroclastic rocks produced the greatest number of landslides; they tended to be highly disrupted masses of rock and earth that fell and slid into jumbled piles of landslide debris. The harder lava-flow rocks also produced many landslides; they consisted primarily of boulders up to several tens of cubic meters in volume that were shaken loose from steep outcrops and then bounced and rolled down steep slopes. These boulders are massive and cause great damage when they hit buildings, vehicles, or people. Thus, though the nature of the hazard may differ, both types of rocks can produce damaging landslides. Mitigating hazards from these two landslide types typically involves very different approaches, and so understanding the geologic setting of potential landslide areas is critically important.

In terms of dealing with landslide hazards related to the earthquake, three perspectives should be considered. First are immediate hazards created by the earthquake that pose current dangers to life and property. Most of these situations had been addressed in the immediate aftermath of the earthquake. The second perspective involves hazards that will be exacerbat- ed in the near future, primarily from strong aftershocks, of which there have been many, and more especially in the upcoming rainy season, which normally begins in May. Such hazards are numerous, and preparing for these hazards in the short time before the rains begin presents a serious challenge. The third perspective is long-term: what can we expect to happen in the next large earthquake or after many rainy seasons? This perspective may have a lower priority in the immediate aftermath of the earthquake, but landslides triggered in this earthquake can provide a useful indication of what hazards to expect and prepare for in future large earthquakes. The most notable example is the Las Colinas landslide: gaining a detailed understanding of what caused that landslide will enable scientists and engineers to identify similar areas that may be at risk of such disasters in future earthquakes and will allow local leaders to take steps to avoid or prepare for such an event. One difficulty in places such as Las Colinas is that development has already occurred up to the base of the slopes; in fact, development in some places has cut well into the base of the slope. This development leaves no room to implement many of the methods normally employed to mitigate landslide hazards, such as constructing stabilization or retention structures. In such cases, officials are left with only two mitigation options that lie at opposite ends of the normal spectrum of choices: they can either do nothing and accept the risk, knowing that more damaging landslides will eventually occur, or they can condemn and remove large numbers of existing houses in areas at risk from future landslides. Neither of these options is particularly desirable, but they may be the only options available in some cases. 
W e visited several sites with personnel from USAID and Salvadoran Government agencies that included sites of reported landslide problems and sites where individuals or organizations requested technical assistance. In general, our visits were relatively brief, and thus our observations and recommendations are likewise brief and preliminary in nature. Many of the sites will require more detailed observation and analysis by technically qualified experts to design and implement comprehensive mitigation strategies. Our recommendations are primarily for meeting short- and intermediate-term hazards and do not preclude the need for more extensive recommendations after further study.

In this report we describe the sites we visited, identify their locations, summarize the hazard situation, and briefly describe mitigation options and recommendations.

\section{CORDILLERA BALSAMO}

Location: Las Colinas landslide: $13^{\circ} 39.662^{\prime}$ N., 89 $17.188^{\prime}$ W.; Balsamo Ridge and the surrounding region to the west and south.

\section{Situation:}

\section{General Geological Setting}

Balsamo Ridge defines the northern boundary of the Cordillera Balsamo. The ridge separates the cordillera to the south from the broad flat valley to the north that is occupied by Nueva San Salvador and Santa Tecla. The Cordillera Balsamo is underlain by the Balsamo Formation, which consists of mafic volcanic breccias, lavas, welded ignimbrites, and other well-indurated volcanic rocks. In the area, the top of the Balsamo

Formation is marked by a weathered soil layer that contains enough clay and fine-grained material that it poses a barrier to downward-draining surface water that percolates through the porous overlying, young volcanic deposits. The Balsamo Formation in the Santa Tecla area is directly overlain by tens of meters of Holocene and Pleistocene volcanic airfall deposits, including a prominent geological marker, the Tierra Blanca 4 tephra (TB4), which erupted from a volcanic source near Lago de Ilopango about 10,000 years ago. The TB4 tephra covered the 10,000-yearold landscape and locally buried it to a depth of $2 \mathrm{~m}$ or more. Since deposition of the TB4 tephra, a series of interstratified volcanic air-fall deposits have accumulated on Balsamo Ridge. The thickness of the TB4 and younger deposits can vary considerably in short distances because they bury a pre-existing landscape, and it is not uncommon for such deposits to be considerably thicker in ancient valleys compared to the adjacent ridges. The generalized stratigraphy of post-Balsamo Formation deposits on the western flank of Cerro La Montana in new exposures at a construction site on the eastern side of Highway CA-4, near the Las Colinas landslide in Santa Tecla, is as follows (simplified from a description provided by James Vallance, U.S. Geological Survey, Vancouver, Washington): 


\section{Depth}

(m)

0-1.0 Tierra Blanca "J" tephra; rhyodacitic fall deposits with $95 \mathrm{~cm}$ of very fine tephra on $5-10 \mathrm{~cm}$ of pumiceous lapilli. Age is A.D.

260-400. 50-cm of brown soil on top.

1.0-2.5 Gray lapilli and tephra, stratified on a 5-cm scale. Possibly from Puerta de la Laguna. $50-\mathrm{cm}$ of brown soil on top.

2.5-3.2 Gray-brown andesitic lapilli and coarse tephra.

3.2-5.7 Rhyodacitic fine to coarse tephra and lapilli. Probably is an airfall deposit or pyroclastic flow unit from Ilopango caldera. Probably is Tierra Blanca 2 tephra but possibly is Tierra Blanca 3 tephra.

5.7-9.2 Andesitic tephra, lapilli, and volcanic bomb-fall deposit; a primary air-fall or reworked fall deposit. Probably derived from Volcán San Salvador. Brown soil in upper part.

9.2-11.2 Andesitic to basaltic andesite fall deposit of lapilli and coarse tephra; bedded on 10-40 cm scale. Probably a Volcán San Salvador deposit named G1.

11.2-11.5 Bedded, coarse, gray tephra fall or surge deposit; brown soil on top.

11.5-15.0 Tierra Blanca 4 tephra. Coarse, rhyodacite tephra and lapilli, pumiceous tephra.

15.0+ Red brown soil developed on underlying deposits; approximately $2 \mathrm{~m}$ exposed.

\section{Las Colinas Landslide}

The January 13 earthquake triggered the Las Colinas landslide off the steep northern flank of Balsamo Ridge (fig. 1). The landslide-a rapid

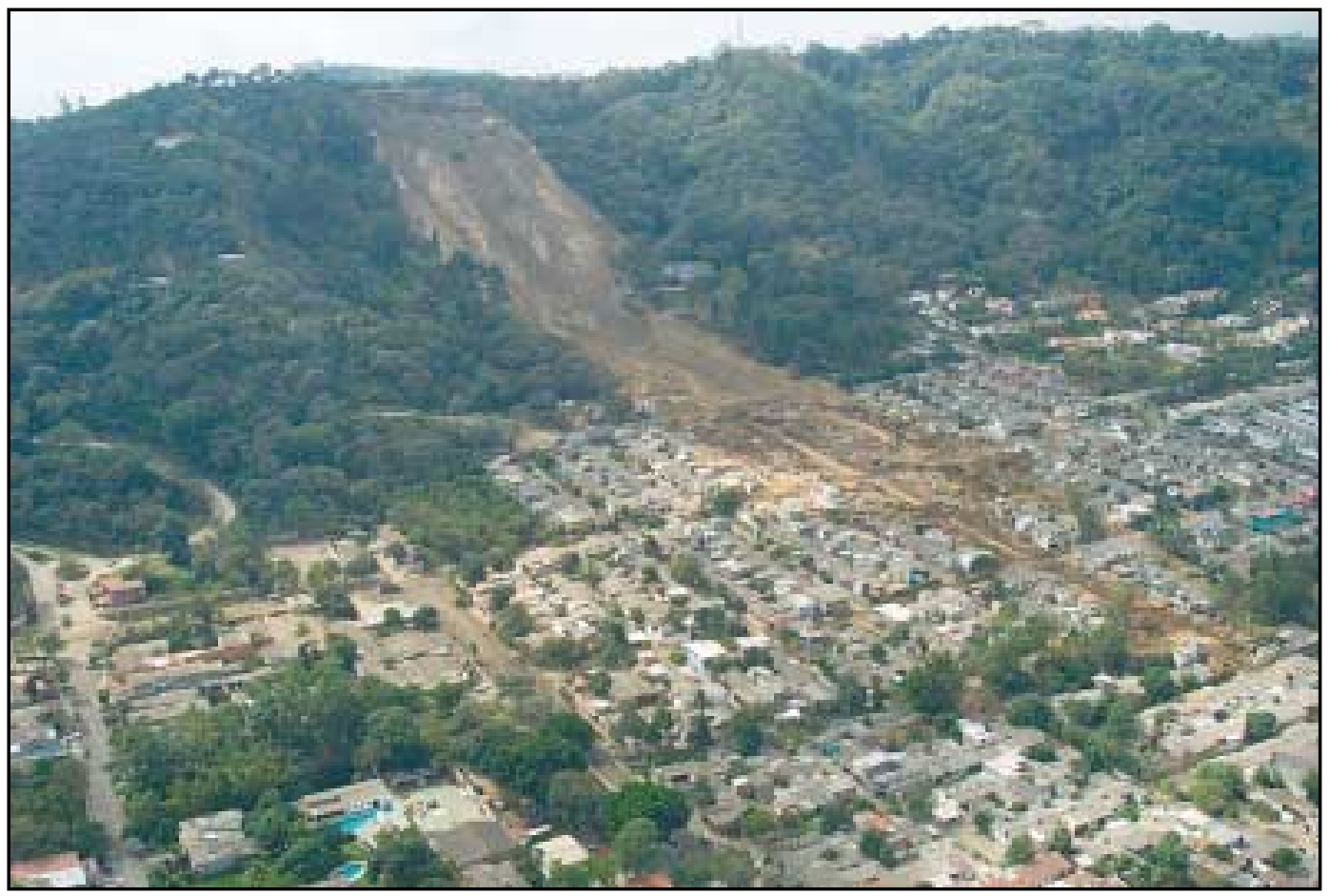

Figure 1. Las Colinas landslide. (Photo by E.L. Harp, USGS) earth flow-originated at an elevation of about $1,070 \mathrm{~m}$ and traveled northward a distance of $700-800 \mathrm{~m}$ into the Las Colinas neighborhood of Santa Tecla. The vertical drop from the landslide source to the terminus is about $160 \mathrm{~m}$. The volume of the landslide material is estimated at about $250,000 \mathrm{~m}^{3}$. The landslide material exposed in the headwall scarp appears somewhat moist but not saturated (fig. 2), but once this material mobilized it behaved as a semi-liquid mass with a soupy consistency; this allowed the mass to travel an unusually long distance from the base of the slope. The transformation of landslide material from solid to fluid in the absence of 


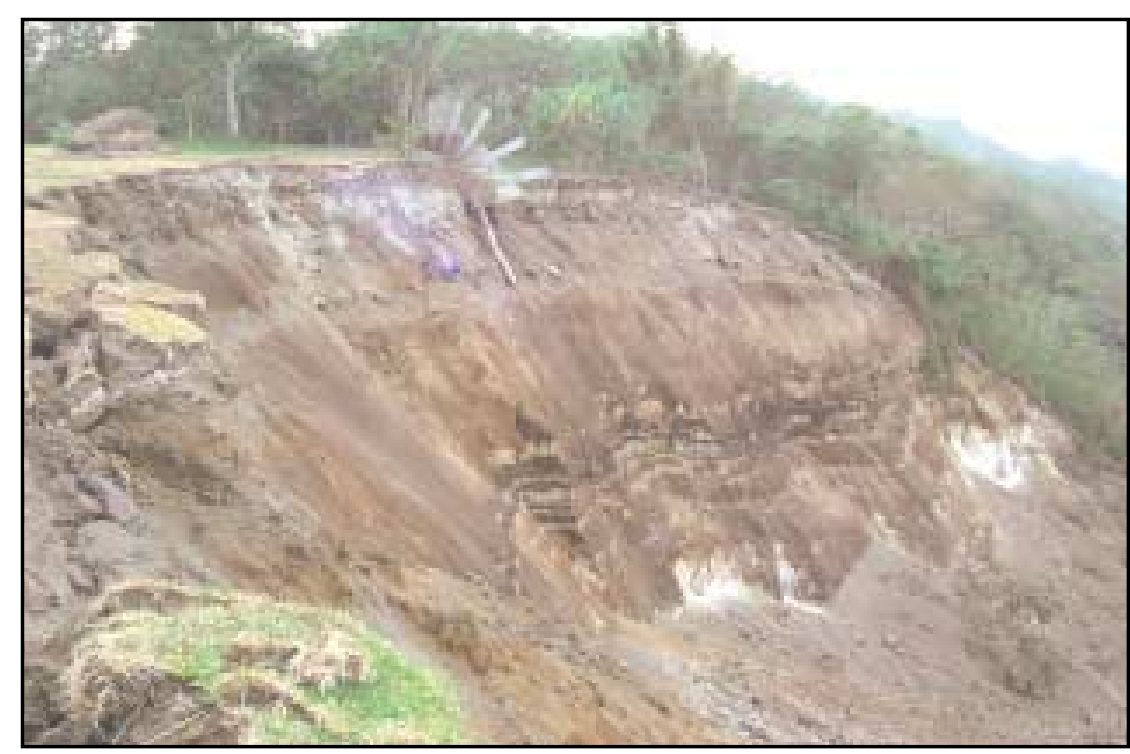

Figure 2. Head scarp of Las Colinas landslide (view to southwest). The whitish layer in the lower right part of the photo is the TB4 tephra. (Photo by E.L. Harp, USGS)

large quantities of water (such as in a heavy storm) and the long runout distance indicate abnormal material behavior that will require detailed investigation and analysis (outlined below).

Evidence on the ridge top indicates very strong levels of ground shaking that far exceed those recorded nearby. Evidence includes trees snapped off, boulders thrown from their sockets, and deep fissures along the edge of the ridge. A strong-motion recording from Santa Tecla recorded a peak ground acceleration of more than
$0.7 \mathrm{~g}$, which is a very high level of shaking at this distance from the epicenter $(>100 \mathrm{~km})$, but shaking on the ridge top appears to have been greater still. This exceptionally strong shaking, along with the presence of thick, loose to poorly consolidated, young volcanic deposits, the steep topography on the northern flank of Balsamo Ridge, and possibly the presence of a relatively impermeable ancient soil at the top of the Balsamo Formation were contributing factors to the triggering of the Las Colinas landslide.

The near-vertical scarp at the landslide headwall exposed the upper 25$30 \mathrm{~m}$ of deposits involved in the landslide (fig. 2). The stratigraphy of these deposits is typical of the volcanic deposits for Balsamo Ridge and much of the surrounding Cordillera Balsamo. Based on reconnaissance work, the locations of abundant earthquake-induced landslides in the Cordillera Balsamo seem to be influenced by the presence of relatively thick deposits of TB4 and the overlying fresh and weathered tephra.

Recommendations: The following recommendations were delivered to the Ministerio de Medio Ambiente y Recursos Naturales:

\section{PRIORITIES FOR LANDSLIDE HAZARD MITIGATION ON BALSAMO RIDGE}

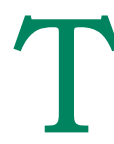

he Las Colinas landslide caused the greatest loss of life in a single location from the M-7.6 earthquake of January 13, 2001. As a result, there is great public concern about the stability of the slopes above Santa Tecla along Balsamo Ridge. These concerns can be divided into two classes: (1) shortterm concerns about landslides triggered by aftershocks and by storms during the upcoming rainy season, and (2) landslides that could be triggered by future large earthquakes similar to that of January 13. Landslides likely to be triggered by aftershocks or during the rainy season are likely to be much smaller than the Las Colinas slide. Cracks are present all along the crest of Balsamo Ridge, but they bound relatively small masses of earth that, if they fail, may not reach the base of the slope and are unlikely to move far 
beyond the base of the slope (fig. 3). Also, loose landslide material still remains in the Las Colinas landslide scar that could move when the rains start, but the volume of this material is small enough that it is unlikely to travel far from the slope base. The potential for large slides in future large earthquakes is more difficult to define and will require detailed study, as outlined below. Listed below is a prioritized list of actions that should be taken to mitigate landslide hazards along the base of Balsamo Ridge:

First Priority: Construct a debris basin below the source of the Las Colinas landslide. This project should begin immediately and be completed before rainy season.

- More landslide material-both from the top of the slope and from within the landslide scar-will inevitably move downslope at the Las Colinas landslide. There is enough space between the base of the slope and the area formerly occupied by houses to construct a basin large enough to catch additional landslide debris. A qualified engineer or geologist should esti-

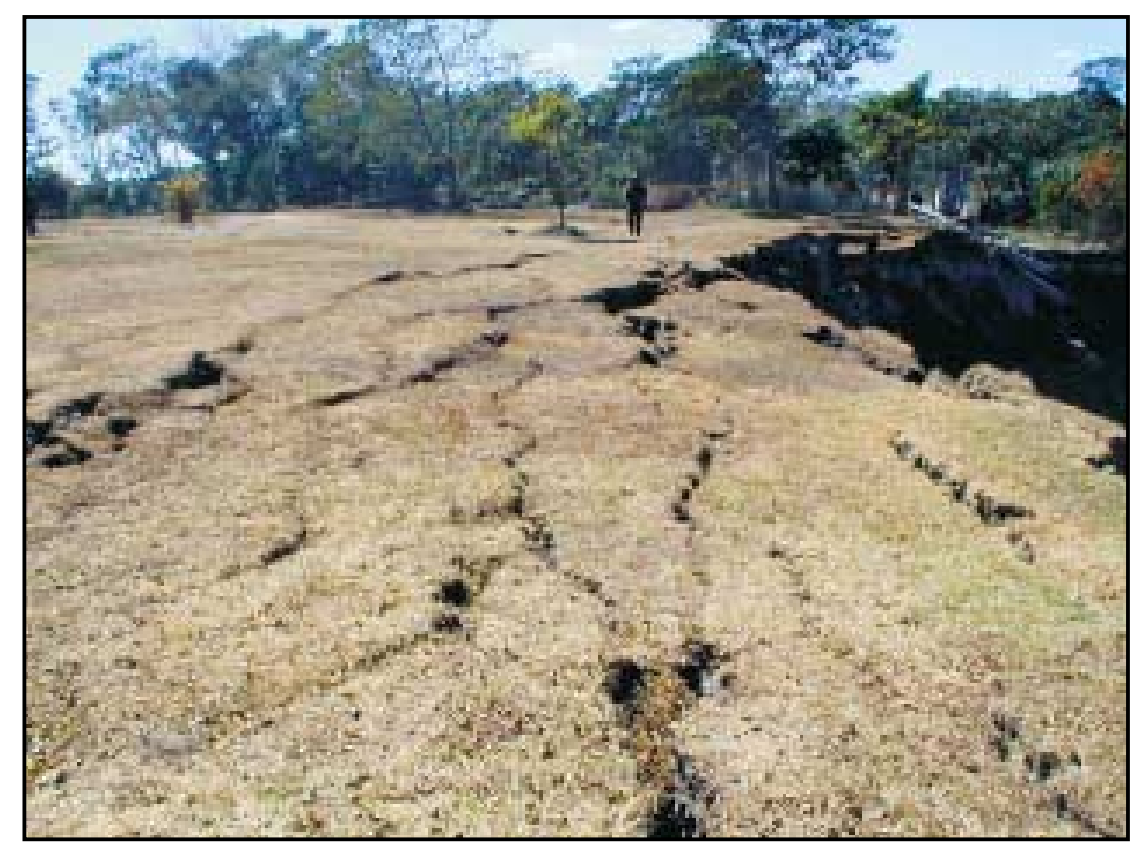

Figure 3. Cracks above head scarp of Las Colinas landslide. mate potential landslide volumes on the slope and design a debris basin with sufficient capacity to impound the material. Part of the landslide and in-place material excavated to create the basin should be used to construct a berm at the downslope end of the basin to further protect developed areas from landslides.

\section{Second Priority: Conduct a} detailed geological and geotechnical study of Balsamo Ridge. The objective of this study is to assess the potential for future large earthquakes to trigger landslides similar to that at Las Colinas somewhere along Balsamo Ridge between CA 4 and Las Delicias (about $3 \mathrm{~km}$ to the west). This study should begin as soon as possible, be completed within a few months, and include the following elements:

- Geologic Study. Define the parts of Balsamo Ridge where Tierra Blanca 4 (TB4) and overlying deposits are relatively thick. Identification of these areas will highlight parts of the ridge where the potential for significant landslides is relatively high.

o Conduct field and airphoto mapping of the stratigraphy in fresh exposures along Balsamo Ridge and surrounding parts of Cordillera Balsamo.

o Combine field-mapping data with results from the drilling study detailed below to develop a map showing the thickness (isopach map) of all volcanic deposits that overlie the Balsamo Formation.

- Landslide Inventory. Locations of existing landslide scarps and deposits along the ridge should be identified by examining large-scale (approximately 1:5,000 scale) airphotos and conducting detailed 
field mapping. Where possible, the maximum runout and volumes of the landslides should be estimated. The geology and morphology of the source areas and landslide masses can then be analyzed to determine areas particularly susceptible failure.

- Geotechnical Study. A landslidehazard analysis requires detailed information on the distribution and geotechnical properties of various types of slope materials. Thus, a program of drilling, sampling, and laboratory testing is needed along the ridge.

o Drilling. Rotary drill holes should be located approximately every $300 \mathrm{~m}$ along the edge of the ridge (total of about 10 holes) and should be drilled to a depth of at least $100 \mathrm{~m}$ or to the base of the Tierra Blanca 4 unit, whichever is deeper. Split-spoon samples should be collected every 3-5 m, and undisturbed tube samples should be collected within each identified unit. Depths of stratigraphic contacts between geologic units should be recorded.

- Laboratory testing. Index properties (grain size, water content, density, Atterburg limits) of split-spoon and tube samples should be measured from standard geotechnical laboratory testing. Shear strengths of undisturbed tube samples should be determined by direct-shear testing.

- Analysis. Results of the above studies should be compiled and analyzed to help determine the factors contributing to failure at Las Colinas and to help identify other slopes along Balsamo Ridge having similar properties that could fail catastrophically. Geologic, geotechnical, and topographic factors contributing to the abnormally long runout of the Las Colinas landslide should be analyzed to provide a basis for estimating runout distances at other possible landslide locations.

- Final Product. The final product of this study should include a detailed written report containing the data and analysis from each phase of the study. Also, a map showing potential landslide sources and runout areas should be included to provide local officials with a practical decisionmaking tool.

The study outlined above requires specialized technical and analytical capabilities that only a few companies possess. Activities such as drilling can be conducted by local contractors, but the overall supervision of the project needs to be under the direction of one of these specialized companies.

\section{BUILDING SITE ON CA-4 AT NUEVA SAN SALVADOR}

Location: $13^{\circ} 39.580^{\prime} \mathrm{N} ., 8^{\circ} 16.698^{\prime} \mathrm{W}$. A foundation pad for an electrical transmission tower is located on a slope in a coffee plantation immediately north of the large fill pad on the east side of CA-4 at Nueva San Salvador.
Situation: Near the foundation pad are several cavernous openings in the slope ranging in size from less than a meter to several meters across. Local people indicate that these caverns did not exist prior to the earthquake. It is difficult to reconstruct a mechanism by which the earthquake could have created 
these caverns. It appears likely that long-term sub-surface erosion (piping) created these caverns and that the roofs of the caverns collapsed during the earthquake exposing them to view for the first time.

Recommendations: No action required. The exposed caverns could be filled and graded over if there are concerns that the caverns are reducing the stability of slopes.

\section{SANTA ELENA}

Location: $13^{\circ} 39.639^{\prime} \mathrm{N} ., 8^{\circ} 15.711^{\prime} \mathrm{W}$. Ridge extending along the southwest edge of Santa Elena.

Situation: A steep ridge extends along the southwest edge of Santa Elena. Massive, hard lava flows crop out on the upper part of this ridge, and these rock outcrops produced rock falls during the earthquake. Fractures in the rock outcrops create rock blocks $1-20 \mathrm{~m}^{3}$ in volume (fig. 4) that can be shaken loose by earthquake shaking; the blocks then cascade down the

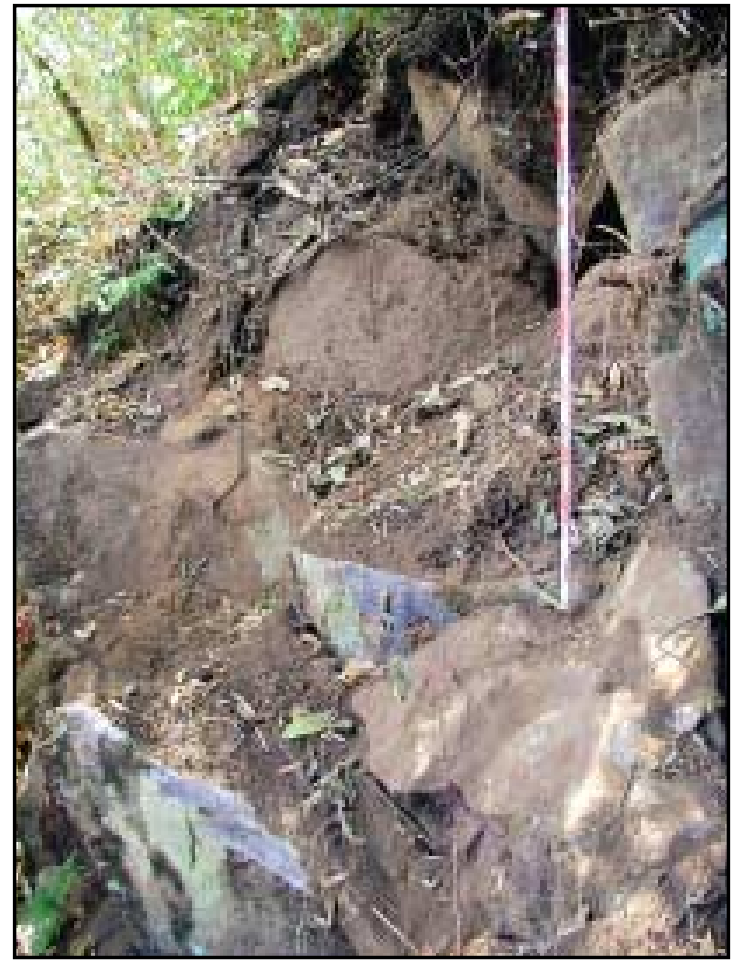

Figure 4. Rock-fall source on ridge above Santa Elena. The boulder shown in Figure 5 came from this source. $30-40^{\circ}$ slope at high enough speed to bounce and become airborne. Several such boulders are strewn throughout the forest all the way to the base of the slope, indicating that this process has been occurring for some time. During the recent M-7.6 earthquake, a $5-\mathrm{m}^{3}$ boulder released from the outcrop (see fig. 4) and moved downslope rapidly enough to knock down a 0.5-mdiameter tree and stop within $30 \mathrm{~m}$

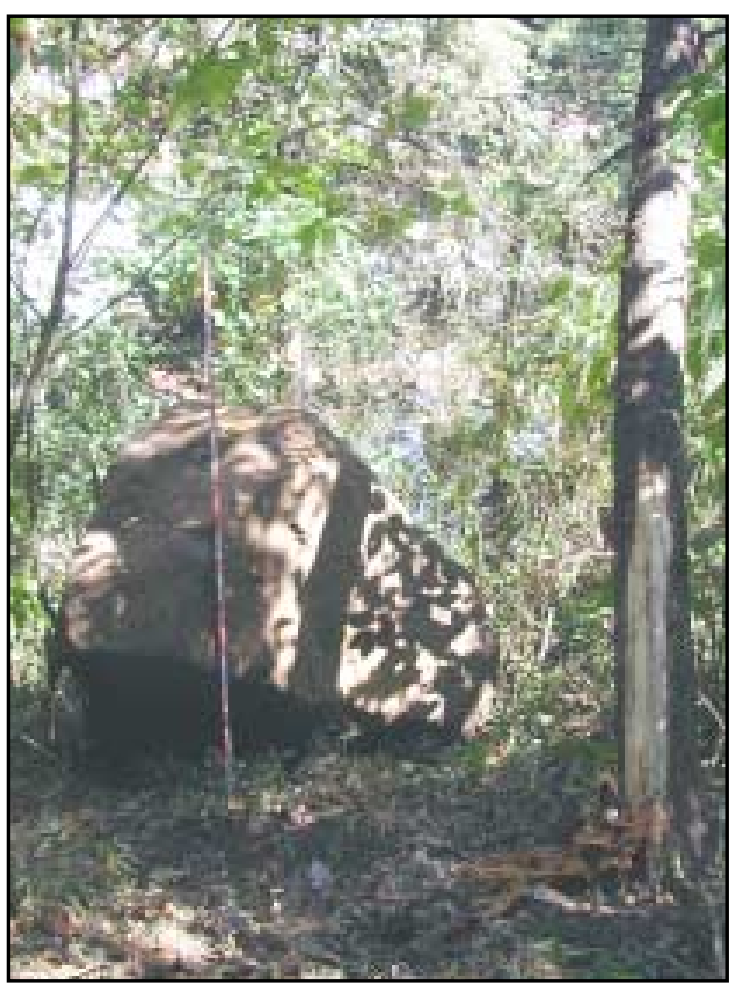

Figure 5. Boulder shaken loose by January 17 earthquake that came to rest near houses in Santa Elena. The measuring stick is 2 meters long. Note the scars on the tree at the right where the boulder tore the bark off the trunk.

of houses at the base of the slope (fig. 5). Had this boulder continued downslope, it would have severely damaged any structure it hit. The hazard from rock falls is greatest along the western end of the ridge and lessens somewhat eastward as the rock-fall sources are higher on the slope in that direction (boulders released higher on the slope are more likely to be slowed and stopped by the thick forest covering the slope). Although heavy rainfall could also trigger rock falls in this area, the greatest hazard is probably from rocks shaken loose in future earthquakes. Houses in this area are built at the base of the slope, and houses in the uppermost part of this neighborhood face the greatest risk.

Recommendations: Several methods exist for mitigating rock-fall hazards. At the rock-fall source, loose boulders can be bolted into 
place to prevent them from falling, or they can be removed in a controlled fashion. Unfortunately, neither of these options is practical at Santa Elena because the rock-fall sources are not accessible with the necessary equipment. At the slope base, retention structures can be constructed; these might include fences, walls, and excavated troughs and berms to catch falling boulders. The best strategy is set-back: leave a buffer between the slope base and any structures to provide a safety zone against rock falls. At Santa Elena, houses already exist very near the slope base, and so set-back is not an option. And because the houses are so close to the slope base there is no room to construct the types of retention structures that would be most effective (troughs and berms). The best remaining option may be to construct a cable fence consisting of heavy-duty steel posts supporting heavy cables designed to stop boulders. Such a cable fence would have to be designed to withstand highspeed impact since it would have to be built at the very base of the slope where some boulders will still be traveling at high speed. Experienced rock-engineering firms can be

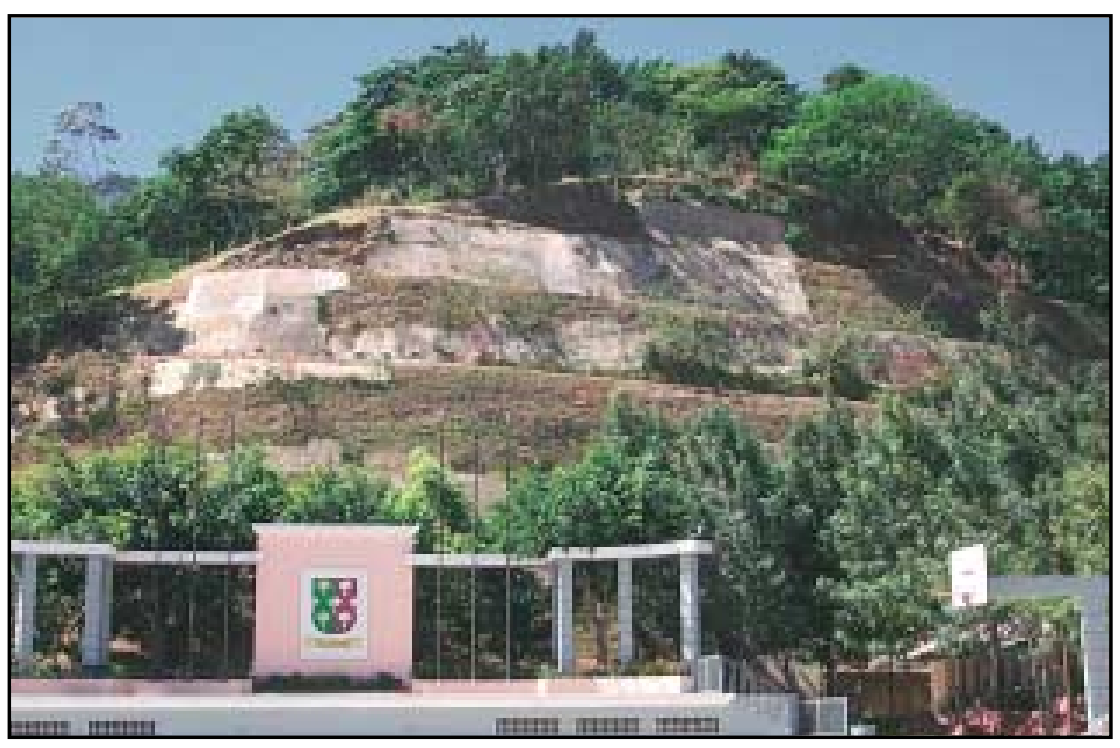

Figure 6. Cut slope above La Floresta school for girls. Scar on upper left part of slope is a small landslide triggered by the January 13 earthquake. retained to design and install such a structure. In the interim, residents should be informed of the hazards and warned to watch for rock falls after earthquakes or heavy rainfall.

\section{RIDGE TOP ABOVE SANTA ELENA}

Location: $13^{\circ} 39.475^{\prime} \mathrm{N}$., $89^{\circ} 15.639^{\prime} \mathrm{W}$. Ridge top above Santa Elena.

Situation: The earthquake opened cracks as wide as $20 \mathrm{~cm}$ in the yards of two houses on the crest of the ridge above Santa Elena. In one case, small cracks extended through the house. Boulders thrown out of their sockets and eyewitness accounts indicate earthquake shaking of about $1 \mathrm{~g}$, a very high level of shaking. The cracks appear to be the result of this very strong shaking; fill present on the crest of the slope also contributed to the formation of cracks: settlement and downslope movement of the fill during the earthquake created many of the observed cracks.

Recommendations: Cracks should be sealed to prevent the infiltration of water during the rainy season. Terracing the slope with retaining wall could help stabilize the fill, which creeps downward annually even in the absence of earthquake shaking.

\section{LA FLORESTA SCHOOL}

Location: $13^{\circ} 38.975^{\prime} \mathrm{N} ., 8^{\circ} 17.287^{\prime} \mathrm{W}$., off CA-4

Situation: The La Floresta school for girls has been evacuated since the M-7.6 earthquake because of structural concerns as well as concerns about the stability of the cut slope behind the school. The school is built at the foot of a cut slope that is about $40 \mathrm{~m}$ high with an average slope of about $60^{\circ}$ (fig. 6). The slope is benched; benches are about $2 \mathrm{~m}$ wide with culvert drains and are separated by $60-70^{\circ}$ risers that are 
either covered by grass, a thin veneer of weak concrete, or a thicker concrete cover over about $1 \mathrm{~m}$ of soil mixed with concrete. The rationale for which parts of the slope are covered in concrete and which are not is unclear; apparently identical sections of the cut slope are treated differently in different areas. Both Hurricane Mitch and the earthquake triggered failures of a few hundred cubic meters along the top tier of the cut slope, and deep cracks remain open there. Also, the top of the ridge far above the cut slope (above the coffee plantation) has extensive open fractures that extend for several tens of meters. School officials are concerned about a Las Colinas-style failure of the slope above the cut slope as well as the stability of the cut slope itself.

The cracks on the top of the ridge appear related to localized amplified ground shaking that caused ridge-top spreading. There are small, shallow landslides in the road cut on the back side of the ridge, but there is no evidence that the cracks on top of the ridge are related to landsliding above the school. The slope between the ridge crest and the cut slope is only moderately steep, and this makes a Las Colinas-style failure very unlikely at this site. The more immediate concern should be the stability of the cut slope above the school.

Recommendations: The material on the top tier of the cut slope that failed during the earthquake needs to be removed and the cracks sealed before the rainy season begins to prevent mobilization of the failed material, which could move rapidly downs- lope and hit the school buildings. That part of the slope then needs to be regraded and reinforced.

To be safe on the longer term, the entire cut slope should be stabilized using a tie-back wall. Such a wall could be covered with reinforced concrete and held in place with anchors drilled into the cut slope and grouted into place. This more comprehensive job of reinforcing and anchoring the entire face of the slope could probably take place over a longer period of time after the school is reoccupied.

\section{LA MATEPEC SCHOOL}

Location: $13^{\circ} 39.108^{\prime} \mathrm{N} ., 8^{\circ} 17.231^{\prime} \mathrm{W}$., off CA-4

Situation: This school is built at the base of a cut slope similar to that at the La Floresta School. This cut slope has some thicker concrete sections along the base, but the entire upper section is either exposed native slope material or thin-veneer concrete (1-2 cm). The slope performed well during the earthquake but has other, longer term cracks and deformations.

Recommendations: The cut slope needs to be re-engineered as described above for the La Floresta School, including a thick reinforced concrete facing and anchors drilled and grouted into the slope. This could probably be safely conducted on the long term after the school is reoccupied. There are no immediate slope hazards preventing the school from being reoccupied while this work progresses. 
Location: $13^{\circ} 36.176^{\prime} \mathrm{N} ., 9^{\circ} 17.161^{\prime} \mathrm{W}$; road cut on west side of CA 4 north of Zaragoza.

Situation: The earthquake triggered a rock fall having a volume of about $2,500 \mathrm{~m}^{3}$ from the road cut at this location (fig. 7). One house was

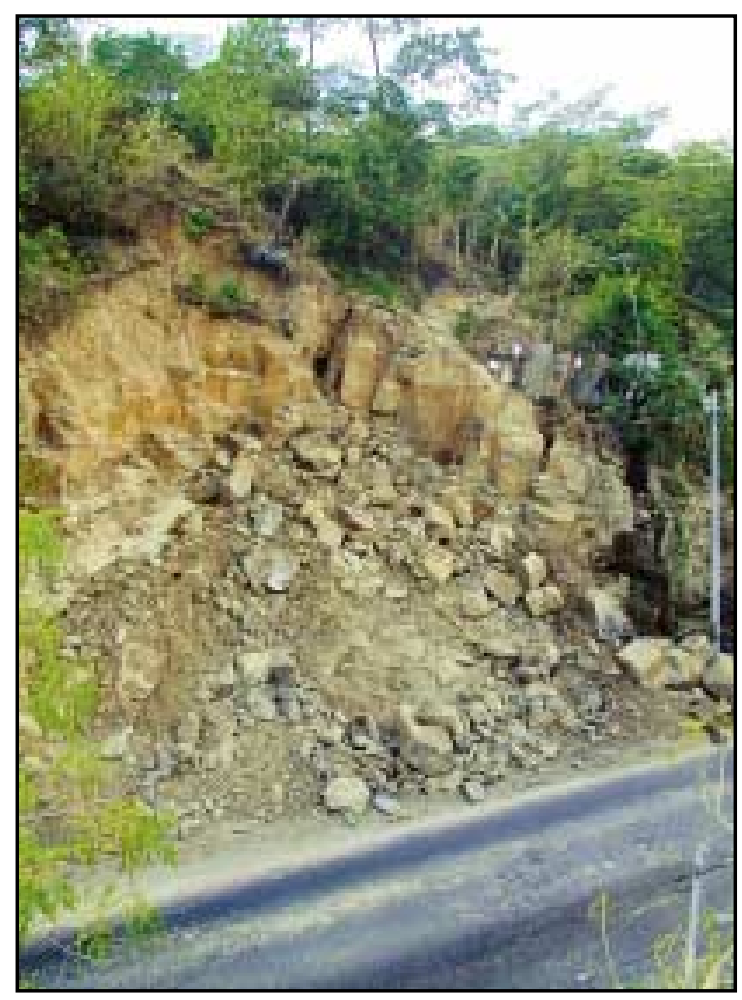

Figure 7. Rock fall between Zaragoza and El Transito.

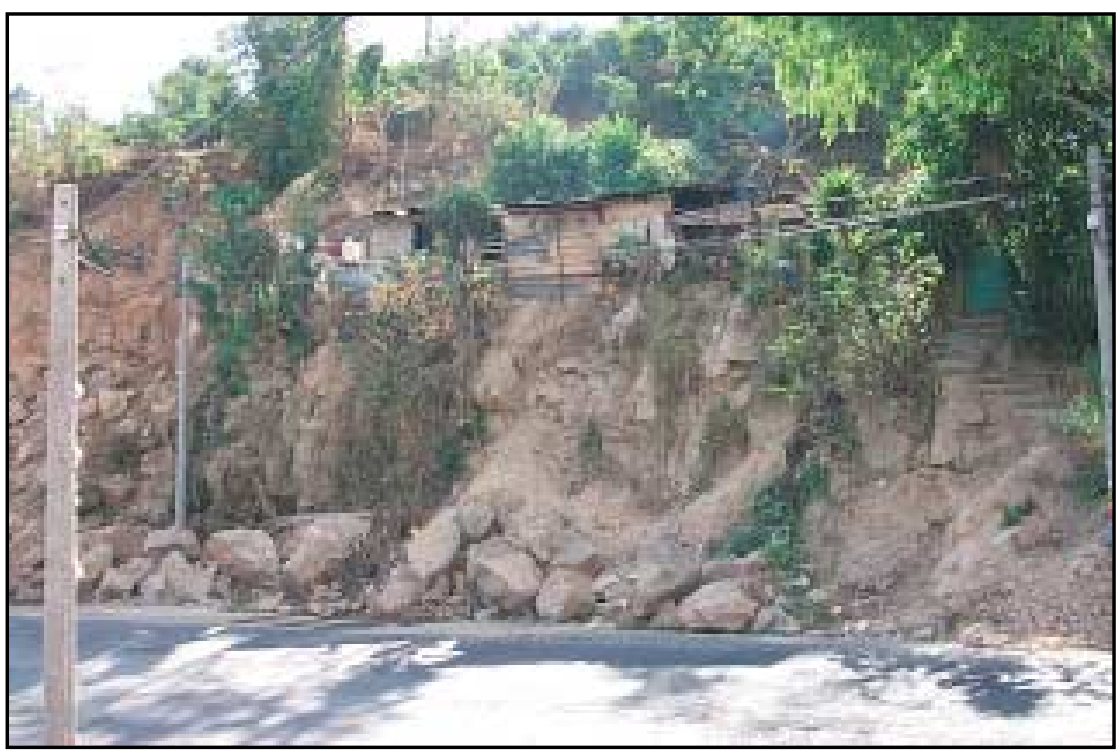

Figure 8. Houses along rock-fall scarp between Zaragoza and El Transito. destroyed in the initial rock fall. Several additional houses are located along the new rock-fall scarp. The rock mass below these houses is fractured and dilated and is at great risk of failing in aftershocks, heavy rainfall, or future large earthquakes (fig. 8). This poses risks to both the residents of the houses and motorists on the road below.

Recommendations: Houses along the fresh scarp should be removed immediately and the residents relocated. Rock-fall material from the earthquake should be removed from the landslide scar, and the rock face should be graded back to a more stable slope angle.

\section{ZARAGOZA-EL TRANSITO}

Location: $13^{\circ} 36.451^{\prime} \mathrm{N} ., 8^{\circ} 17.069^{\prime} \mathrm{W}$, east edge of CA-4

Situation: The earthquake shaking created cracks along the east side of the road (CA-4), probably related to minor slumping of the slope below the road. The crack on the road has only about $2-3 \mathrm{~cm}$ of offset and is closed. The crack at the side of the road has several centimeters of displacement and was open until local residents filled it. Some small houses below the cracks were destroyed by the earthquake shaking and associated minor slope movement.

Recommendations: The cracks probably pose no significant threat to the area, but to be safe local residents can visually monitor the cracks during the rainy season to see if any renewed movement is occurring. If so, residents downslope from the cracks should temporarily evacuate until the cracks have been examined by a qualified engineer. 


\section{ZARAGOZA-ALTA DEL RIO}

Location: Alta del Rio area near Zaragoza.

Situation: Small blocks of rock fell on a home from a 1-2-m-high cut slope behind the house.

Recommendations: Homeowner can grade slope back to a less steep angle. No serious ongoing hazards.

\section{ZARAGOZA-SANTA TERESITA}

Location: $13^{\circ} 35.327^{\prime} \mathrm{N} ., 8^{\circ} 17.619^{\prime} \mathrm{W}$; Santa Teresita neighborhood of Zaragoza.

Situation: Several houses are located below and near vertical rock faces that produced rock falls during the earthquake. The faces are moderately fractured and could produce future rock falls during earthquakes or intense rainfall. The face on the east end of this area is particularly hazardous and has a large $\left(10 \mathrm{~m}^{3}\right)$ boulder that is detached and ready to fall (fig. 9). Several houses are directly in the path of this boulder.

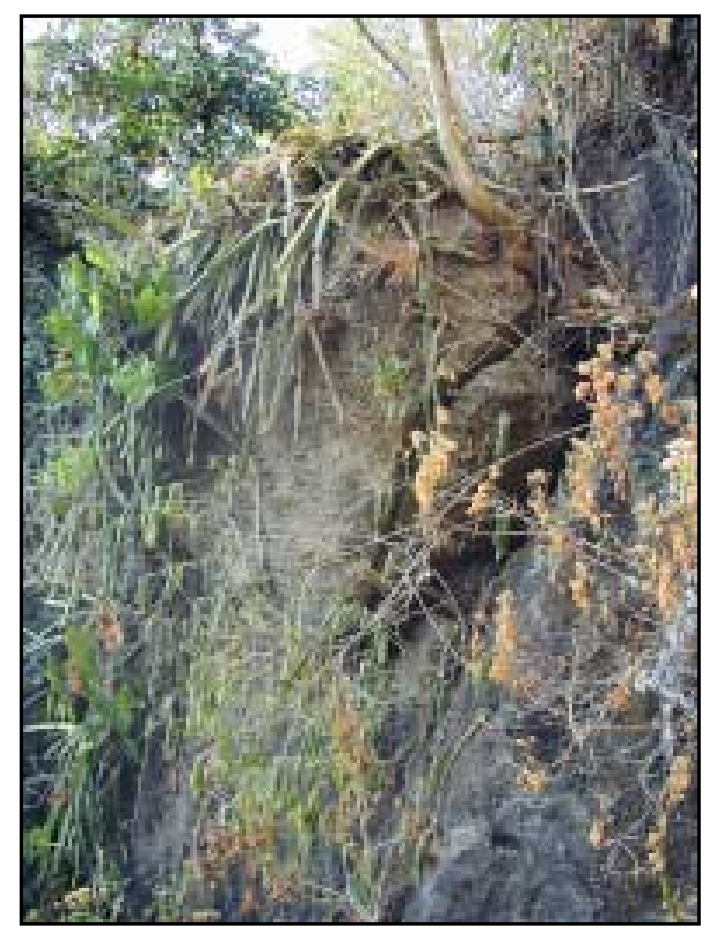

Figure 9. Precariously perched boulder above houses in Santa Teresita.
Recommendations: Removal of the precariously perched boulder from the eastern rock face would be the most effective course. This will require attaching cables to the rock and either pulling it to the top of the slope with heavy equipment or causing it to fall with restraints so that it will not continue into the houses below. Cable fences to catch boulders could be installed in other areas below the rock faces to prevent boulders from hitting houses or blocking the street.

\section{ROAD FROM LAS DELICIAS TO COMASAGUA}

Location: Spot locations along road: $13^{\circ} 40.558^{\prime} \mathrm{N} ., 8^{\circ} 20.262^{\prime} \mathrm{W}$.; $13^{\circ} 40.304^{\prime} \mathrm{N}$., $89^{\circ} 20.262^{\prime} \mathrm{W}$.

Situation: Almost the entire length of the road extends along a narrow, steep-sided ridge. The ridge experienced amplified ground shaking and is thoroughly shattered along most of its length (fig. 10). The ground surface is fissured and shattered, road cuts have failed continuously, and nearly all structures have collapsed. The road is in very poor condition-it is covered by as much as $0.5 \mathrm{~m}$ of fine, powdery dust, and the failed road cuts are depositing more material on the road (fig. 11). When this material gets wet in the rainy season, the road is likely to be impassable. On the east end, the road traverses a large, deep debris slide triggered by the earthquake that is similar to the Las Colinas landslide.

Recommendations: The road cuts should be stabilized by regrading and removing failed material. The road itself needs to be regraded to remove the thick layer of dust; it should then be graded with gravel or other aggregate to provide stability to the road base. This needs to occur before the rainy season if the road is to remain open. Keeping the road open across the large landslide at the east end may be very difficult. It may require building retaining walls above the road to catch additional landslide material that is likely to fall from the scarp area. 


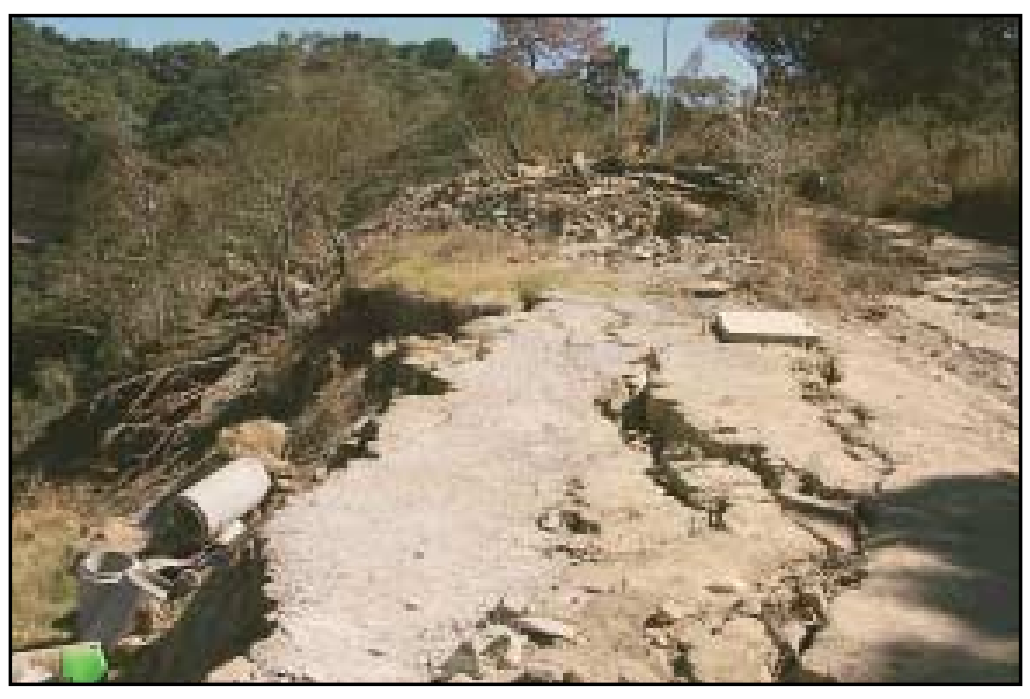

Figure 10. Shattered ridge near Comasagua.

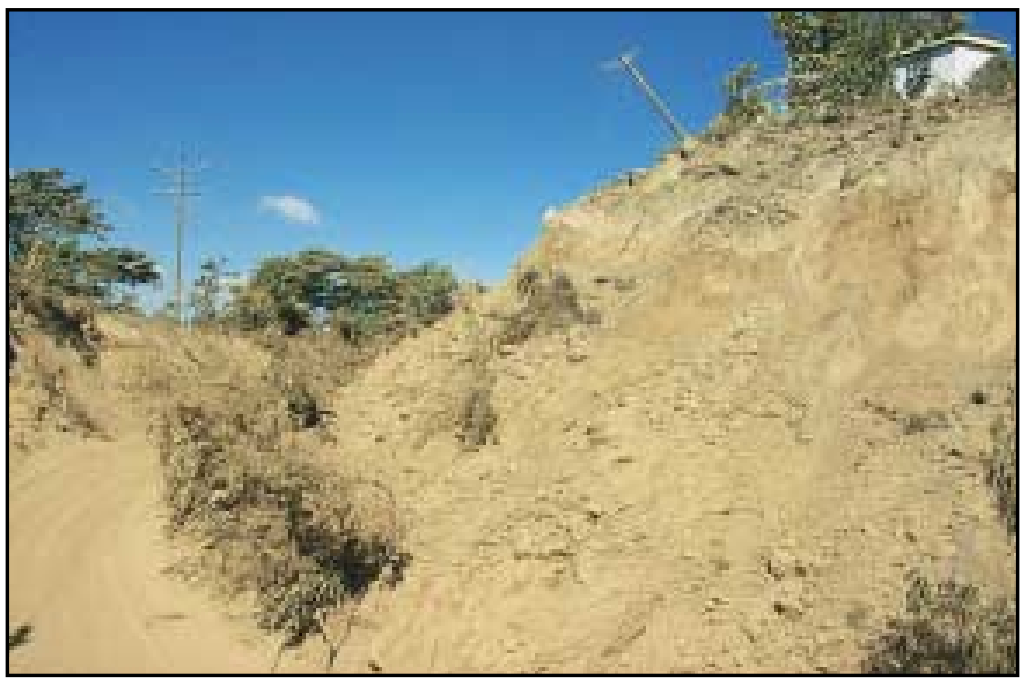

Figure 11. Road-cut failures on road from Las Delicias to Comasagua.

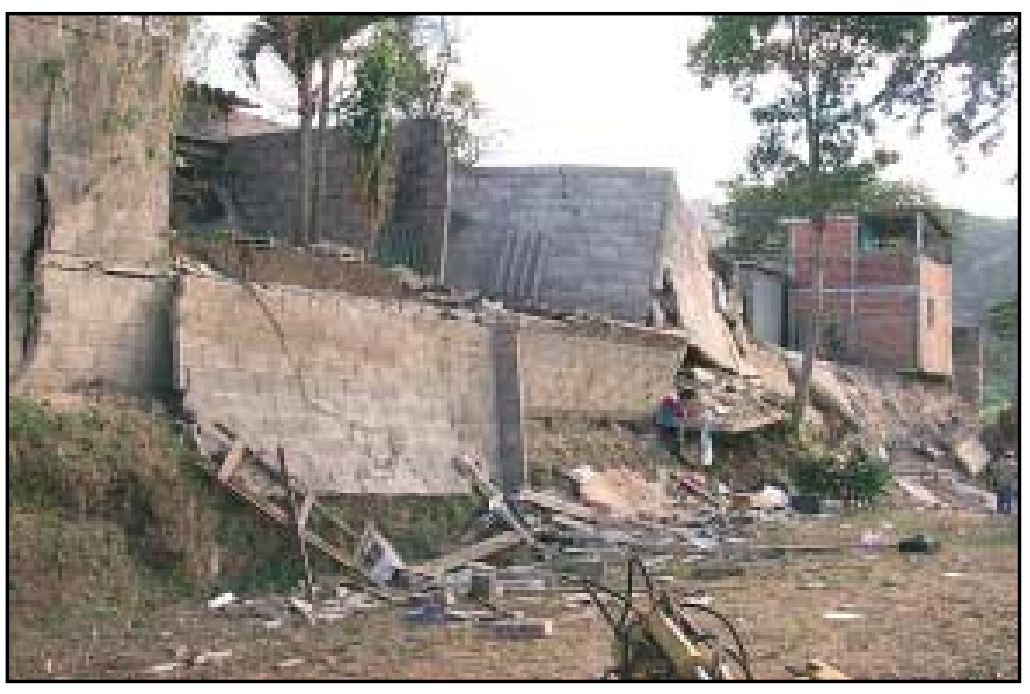

Figure 12. Damage from strong shaking and landsliding at Alpes Suizos.

\section{ALPES SUIZOS}

Location: $13^{\circ} 40.740^{\prime} \mathrm{N} ., 8^{\circ} 18.887^{\prime} \mathrm{W}$; west end of Santa Tecla overlooking Pan-American Highway.

Situation: Several houses built on the edge of the slope overlooking the highway were severely damaged during the earthquake by a combination of strong shaking and failure of the slope beneath the houses (fig. 12). The rear half of the houses detached in many cases and moved several centimeters toward the slope. Houses across the street to the east also had serious cracking and damage but not as severe. The area is currently evacuated, and many residents are eager to repair and rebuild their homes.

Recommendations: The likelihood of continuing slope movement is high, both in earthquakes and rainfall, and the slope movement will be difficult to stabilize economically and reliably. The cost of slope stabilization will likely be much greater than the value of the affected houses; therefore, the houses on the outer edge of the slope should be condemned and removed rather than repaired. The houses on the east side of the street could be repaired and salvaged if a detailed study indicated that the slope failure will not extend that far behind the edge of the slope.

\section{MADRESELVA}

Location: New development east of Santa Elena.

Situation: This new development has extremely steep roads, road cuts, and lots. Many of the steep slopes, if developed, are likely to have severe erosion and slope-stability problems.

Recommendations: Re-examine the permitting process to reassess the viability of this development. 


\section{LA CIMA 3}

Location: $13^{\circ} 39.817^{\prime} \mathrm{N} ., 8^{\circ} 12.965^{\prime} \mathrm{W}$.

Situation: Cracks as wide as $10 \mathrm{~cm}$ opened during the earthquake. The cracks separate road pavement and extend through several houses, causing serious damage (fig. 13). The cracks appear to occur near the boundary of the cut slope and the fill slope, a situation that has been observed in earthquakes elsewhere. Renewed cracking in future earthquakes is likely, and failure of the edge of the fill during the rainy season is possible.

Recommedations: Cracks should be carefully filled and sealed before the rains begin. Homeowners should be informed that renewed cracking is likely in future earthquakes and rainy seasons. A detailed geotechnical study should be conducted to determine the stability of the edge of the fill in the rainy season. Homes below

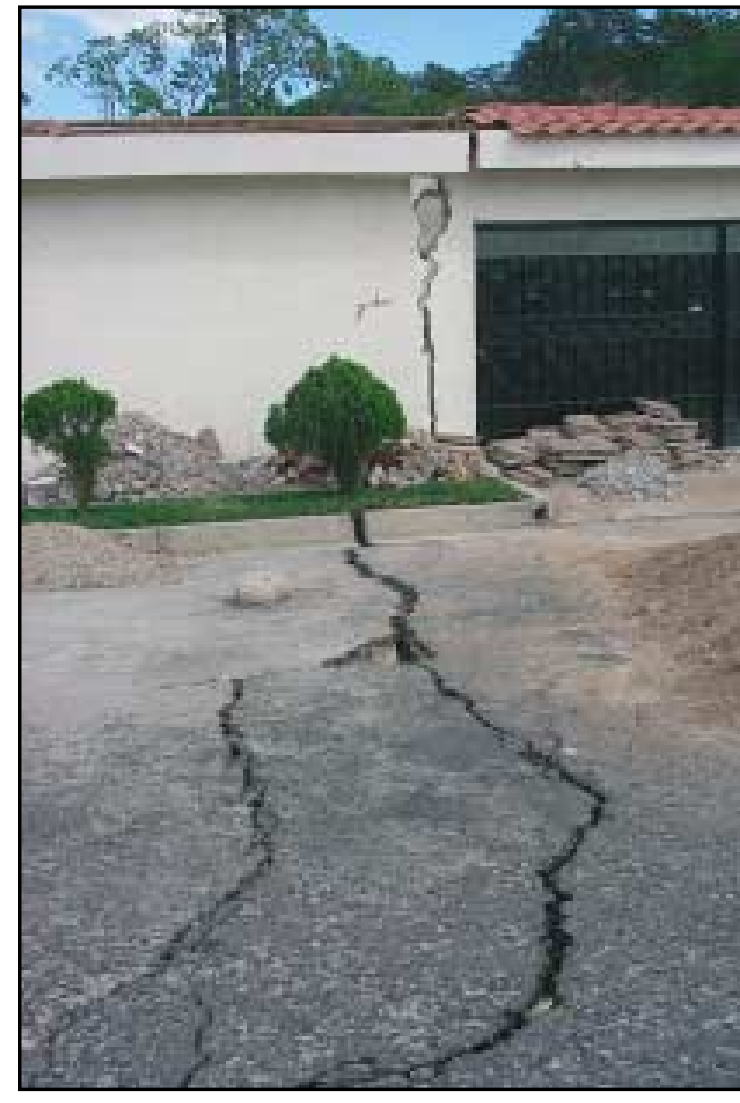

Figure 13. Cracks along the edge of a fill slope at La Cima 3.

\section{LA CIMA 4}

Location: East of La Cima 3

Situation: This is an area currently under construction. There are huge cut slopes and fill slopes. No serious earthquake-related damage was observed. Fill slopes may be susceptible to cracking similar to that in $\mathrm{La}$ Cima 3 in future earthquakes.

Recommendations: Monitor fill slopes for cracking in future earthquakes.

\section{LANDSLIDE ON PAN-AMERICAN HIGHWAY}

Location: $13^{\circ} 39.963^{\prime} \mathrm{N}, 8^{\circ} 48.738^{\prime} \mathrm{W}$; on Pan-American Highway near San Vicente.

Situation: The earthquake triggered a massive debris slide from a road cut on the Pan-American Highway (fig. 14). The slide is approximately $250 \mathrm{~m}$ wide at its base, $120 \mathrm{~m}$ high, and $25 \mathrm{~m}$ thick, which yields an estimated volume of 500,000-700,000 $\mathrm{m}^{3}$. The main scarp of the landslide formed along the surface of a southdipping normal fault, which created a zone of weakened, sheared material

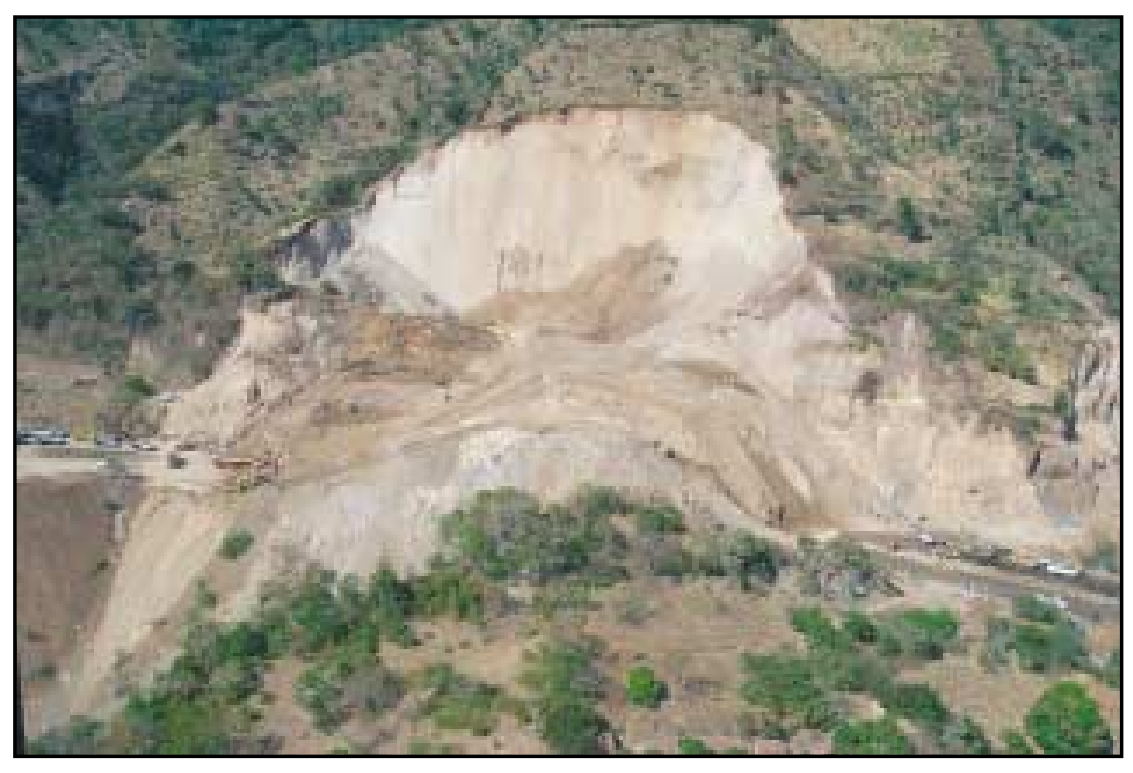

Figure 14. Landslide blocking the Pan-American Highway near San Vicente. (Photo by E.L. Harp, USGS) 
that facilitated slope failure during the earthquake shaking. Excavation of the landslide deposit from the road was almost complete as of February 7,2001 . Local residents stated that the road cut had been oversteepened by people excavating rocks from the cut to sell as building aggregate. We inspected the slope above the crown of the landslide and saw no open cracks or other indications of impending failure of material above the scarp, but near-vertical scarps in weak material commonly retreat through time, so small landslides from the scarp should be expected; most of these will come to rest on the remaining landslide deposit that is above the road. Landslide material removed from the roadway was dumped over the edge of the slope below the road. This uncompacted fill slope is highly susceptible to failure during rainy periods or future earthquakes, which could endanger homes downslope.

Recommendations: Water will tend to collect on top of the remaining landslide deposit, which is above the highway. A drainage system should be installed to keep as much water as possible from the top of the landslide material. The cut slope above the road in the landslide material is rather steep and can be expected to produce small- to moderate-size landslides that could close the road and endanger motorists in rain storms or moderate to large earthquakes; therefore, this cut may need to be laid back to a gentler slope angle. The waste slope below the road will be diffi- cult to stabilize and will require a detailed geotechnical study to recommend solutions.

\section{BERLIN GEOTHERMAL GENERATING FACILITY}

Location: $13^{\circ} 30.947^{\prime} \mathrm{N} ., 8^{\circ} 30.740^{\prime} \mathrm{W}$., Well TR2

Situation: A rock fall of several hundred cubic meters occurred on the steep slope behind the well; the slope is the scarp of an older, larger landslide. Several boulders from the rock fall stopped within a few meters of the well equipment; the biggest single boulder is about $5 \mathrm{~m}^{3}$ (fig. 15). Another landslide heads just below the road to the well. The road itself has cracks parallel to the edge of the slope.

Recommendations: More boulders are likely to come off the slope above the well in future earthquakes and heavy rain storms. The best solution may be to construct a cable fence to catch and stop the boulders at the base of the slope. The fence will need to be designed by a qualified rock engineer and constructed to specifications if it is to perform properly.

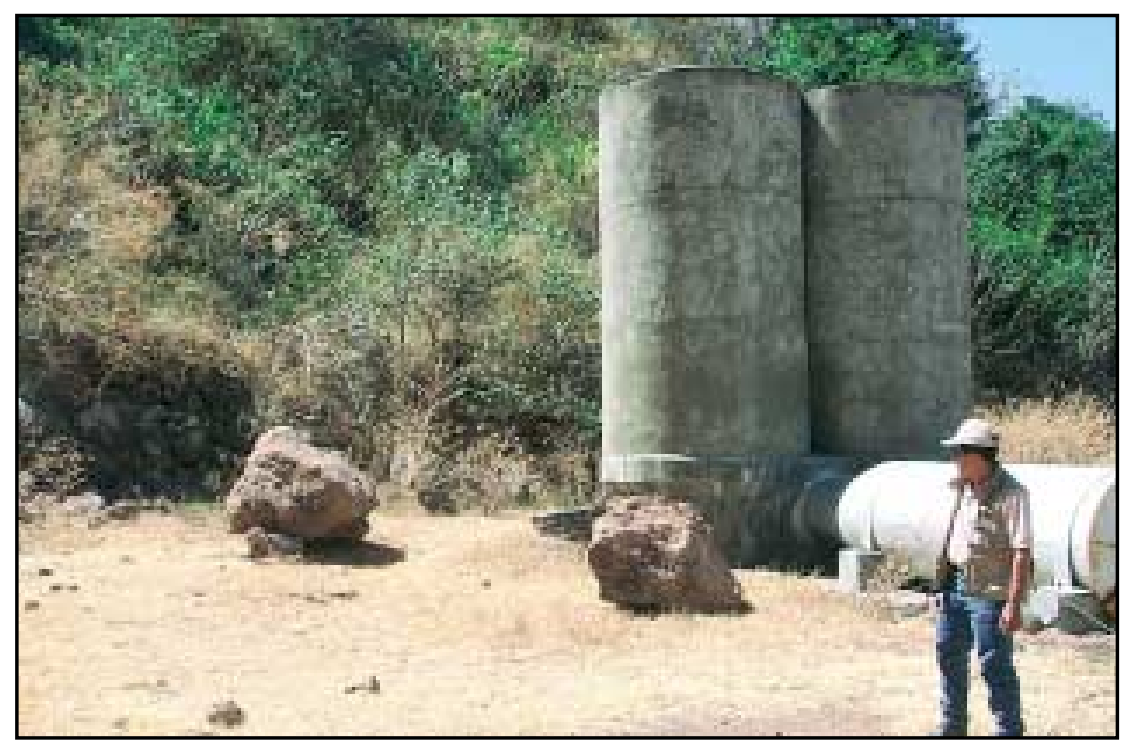

Figure 15. Boulders from rock fall above geothermal well near Berlin. 
The landslide below the road poses no immediate threat.

\section{ROAD FROM BERLIN TO ALEGRIA}

Location: Noteworthy failures at $13^{\circ} 30.345^{\prime} \mathrm{N}$., $88^{\circ} 30.455^{\prime} \mathrm{W}$. and $13^{\circ} 30.437^{\prime} \mathrm{N}$., $88^{\circ} 29.853^{\prime} \mathrm{W}$.

Situation: The road from Berlin to Alegria has numerous rock falls from the earthquake (fig. 16). In places, both sides of the road have large, continuous piles of landslide debris that has been removed from the road. Some of the larger rock falls have volumes of several thousand cubic

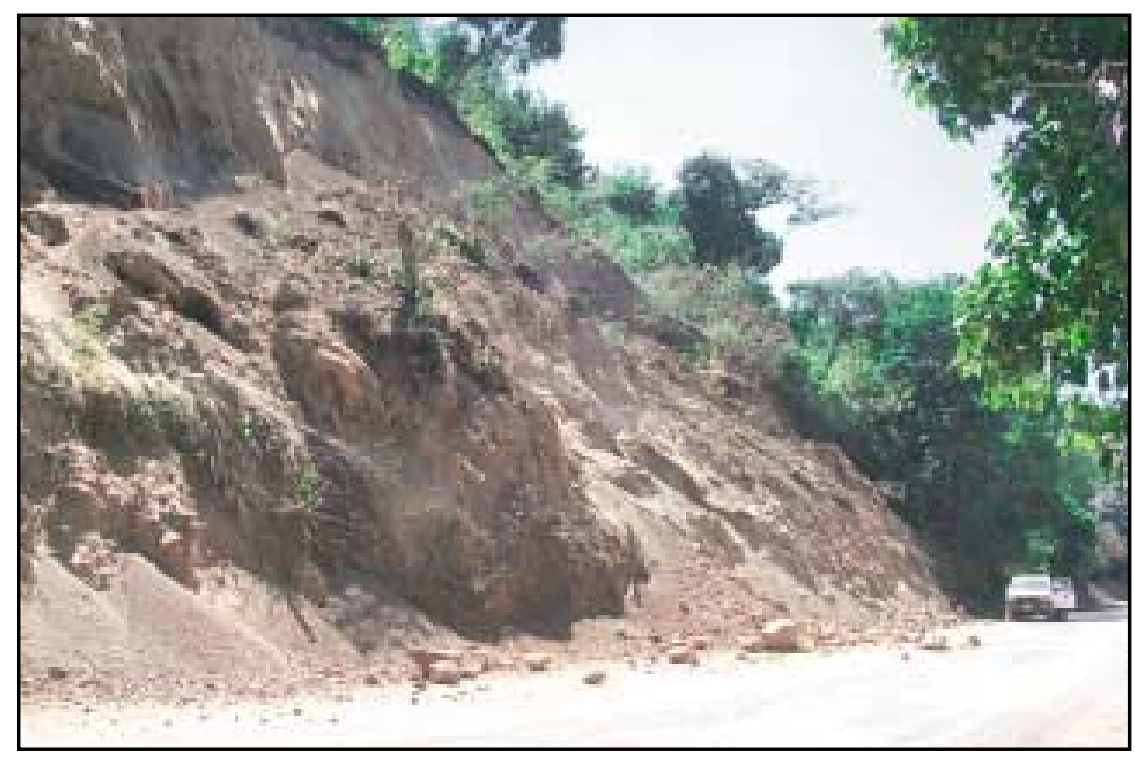

Figure 16. Landslide on road from Berlin to Alegria.

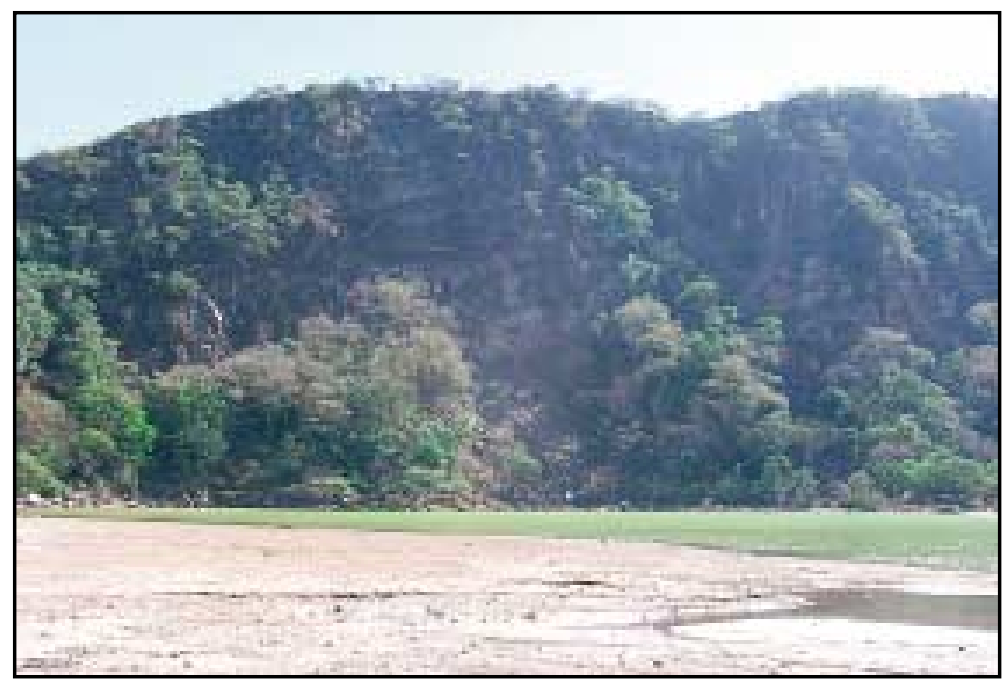

Figure 17. Rock falls from slopes surrounding Laguna Alegria. meters. At least one also failed during Hurricane Mitch. Some of the rockfall scars have open fractures and precariously perched boulders, indicating that more rocks will fall during future earthquakes and storms.

Recommendations: Some boulders that are ready to fall can be removed carefully by properly trained construction crews. Local officials should be informed that landslides along the road should be expected in future earthquakes and during the rainy season.

\section{LAGUNA ALEGRIA}

Location: $13^{\circ} 29.563^{\prime} \mathrm{N} ., 8^{\circ} 29.523^{\prime} \mathrm{W}$.

Situation: The earthquake triggered several rock falls on the crater walls surrounding Laguna Alegria. Rockfall volumes are as great as a few thousand cubic meters (fig. 17). Some rock falls closed the road around the lake. More rock falls can be expected from the steep crater walls.

Recommendations: Clear the road of rock-fall debris and be prepared for future rock falls. Post signs warning visitors of the possibility of rock falls.

\section{ROAD FROM ALEGRIA TO SANTIAGO DE MARIA}

\section{Location: $13^{\circ} 30.264^{\prime} \mathrm{N}$., $88^{\circ} 28.601^{\prime} \mathrm{W}$.}

Situation: The earthquake triggered many rock falls along the road having volumes as great as to several hundred cubic meters. The largest of these (at the coordinates given above) is particularly hazardous (fig. 18). Many dilated fractures have openings of $10 \mathrm{~cm}$ or more. Many boulders are precariously perched and ready to fall. Modest rainfall or earthquake shaking will bring down more material unless immediate remedial work is undertaken 
Recommendations: The road cut needs to be stabilized by removing loose boulders and perhaps using additional rock engineering measures to stabilize the rocks.

\section{USULUTAN VOLCANO}

Location: Usulutan Volcano east of Santiago de Maria

Situation: Many large landslides occurred on the flanks of Usulutan Volcano (fig. 19). They probably affect only the coffee plantations on the slopes, but sediment from these land-

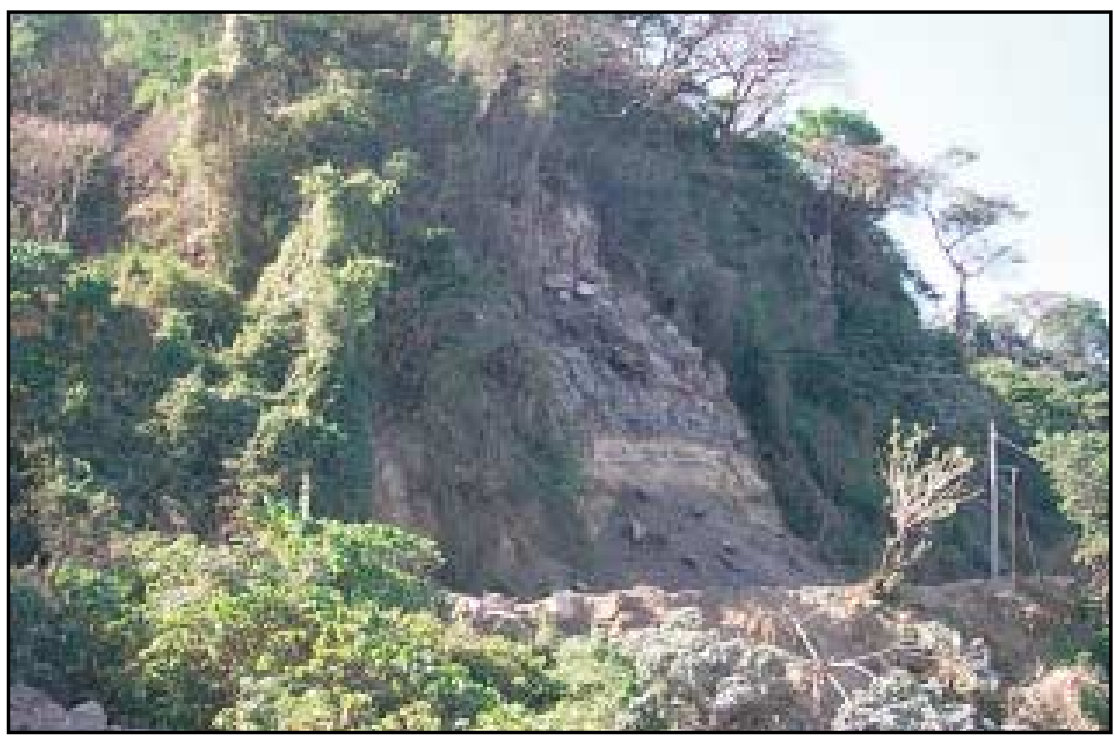

Figure 18. Rock fall on road from Alegria to Santiago de Maria.

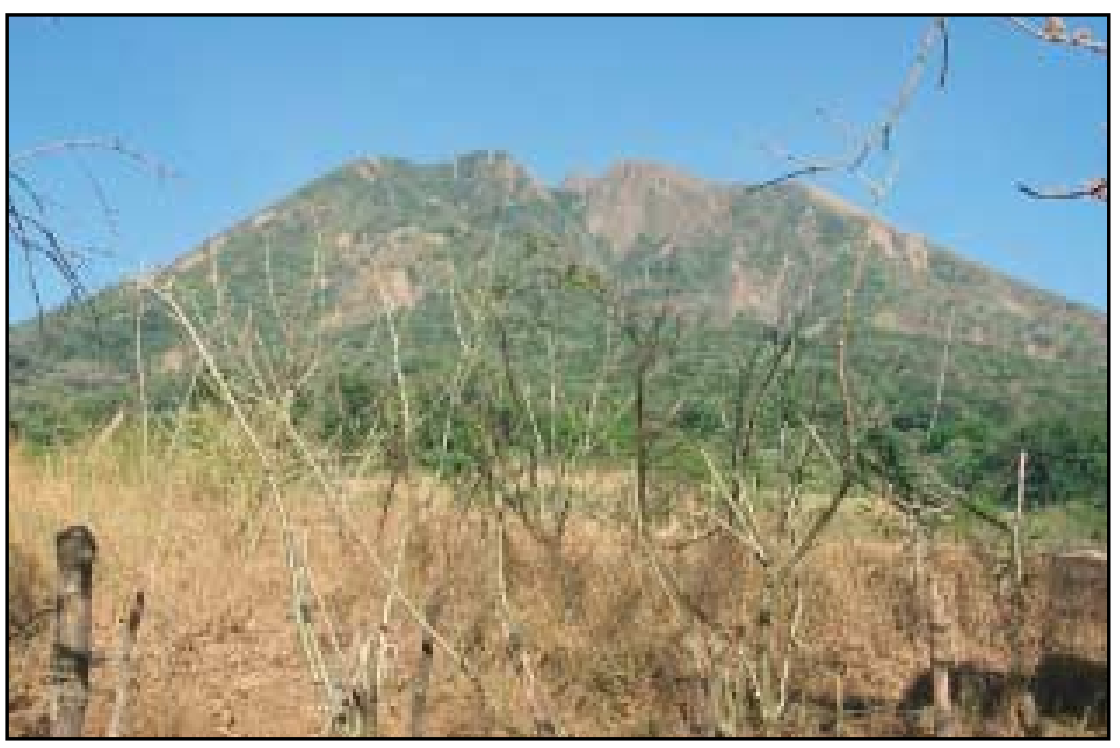

Figure 19. Landslides from the flanks of Usulutan volcano. slide deposits will wash into drainages over time and could cause sedimentation problems downstream.

Recommendations: Plantation owners should address landslide problems. Communities downstream from the flanks of the volcano should be warned of possible sedimentation issues in the future.

\section{ROAD FROM SANTIAGO DE MARIA TO USULUTAN}

Location: $13^{\circ} 26.569^{\prime} \mathrm{N}$., $88^{\circ} 29.048^{\prime} \mathrm{W}$.

Situation: The earthquake triggered a debris fall in a road cut. The landslide material is dry, powdery dust from volcanic tephra. When the rains begin, this road cut will likely produce additional failures that may close the road.

Recommendations: Grade road cut back to more gentle angle to reduce likelihood of additional failures.

\section{SAN PEDRO MASAHUAT}

\section{Location: San Pedro Masahuat}

Situation: This town is built on a very thick layer of white, powdery volcanic tephra. Deep gorges have been eroded into the ash deposits on the edge of town. These gorges have nearly vertical walls $70-80 \mathrm{~m}$ high and are about $50 \mathrm{~m}$ or more wide. The earthquake triggered massive failures along the walls of the gorges; blocks and slabs of material hundreds to thousands of cubic meters in volume cascaded to the base of the very steep slopes (fig. 20). Numerous cracks and fissures parallel to the edge of the gorge and as far as $30 \mathrm{~m}$ from the edge define additional slabs of material that are likely to fail in the rainy season or in future earthquakes. The head of one gorge is already undermining the edge of a street in the town, and headward erosion will undermine this street until it is 


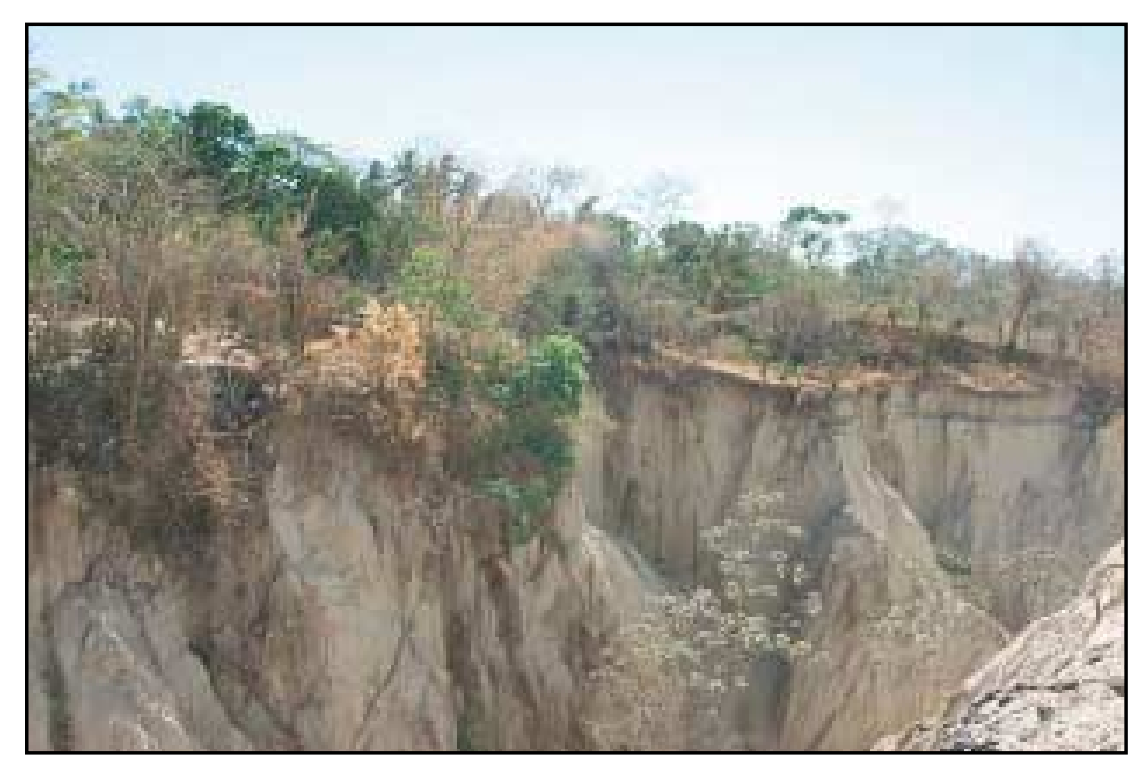

Figure 20. Failures of near-vertical slopes in San Pedro Masahuat. accommodate this situation and plan to adapt to the inevitable consequences. The first priority is life safety; therefore, houses very near (within a few meters) the current edge of the gorge need to be removed and the residents relocated. Additionally, houses between large cracks parallel to the edge of the gorge and the edge of the gorge itself may also need to be removed; in such situations, the houses are on a potential landslide block that could fail catastrophically during earthquakes or the rainy season. A thorough investigation of the locations of cracks should be made by carefully inspecting areas along the edge of the bluff and recording houses with nearby cracks. Filling open cracks with dirt or cement will prevent infiltration of water in the rainy season and may delay the failure of new areas outlined by cracks. The second priority is to make a long-term plan to accommodate the retreat of the walls of the gorge. Local officials may want to establish a setback limit from the edge of the gorge. A limit of about $30 \mathrm{~m}$ may be reasonable, but the limit should be set based on the observed distance of earthquake-related cracks from the edge of the bluff. Homes within this 30-m set-back zone would be scheduled for relocation over the next few years as resources are available. This will allow the natural process of bluff recession to occur within a safe zone where no houses exist. The street at the head of the gorge will become impassible soon, and plans should be made immediately to relocate this street. 
he January 13, 2001 earthquake off the coast of $\mathrm{El}$

1 Salvador triggered thousands of landslides over a broad region of the country. Areas most affected by landslides include the Cordillera Balsamo region west and south of San Salvador, areas around Lago de Ilopongo and Lago Coatepeque, slopes on the flanks of volcanoes in the southern part of the country (particularly Usulutan Volcano), and several slopes around San Salvador proper. Geologic units most affected by landslides include the Balsamo Formation and the younger pyroclastic units that overlie the Balsamo Formation, particularly the Tierra Blanca 4 tephra unit. Two of the largest triggered landslides caused most of the landslide-related damage and fatalities: the Las Colinas landslide destroyed a neighborhood in Santa Tecla and killed about 500 people, and a landslide near San Vicente closed the Pan-American Highway and killed 12 people.
Renewed landslide activity can be expected in future rainy seasons and future moderate or large earthquakes. Landslide hazards should be evaluated and considered in post-earthquake reconstruction efforts as well as ongoing development. Such hazards are much more easily mitigated prior to development than after it has already occurred. Santa Tecla is an example of the difficulty in mitigating landslide hazards after development has occurred: with existing development extending to the base of Balsamo Ridge, few economically or politically viable options exist to mitigate hazards from future landslides from the steep slopes of the ridge.

Implementing mitigation measures recommended in this report or by other qualified experts should help reduce damage and fatalities from future landslides. 